\title{
GBA in Teaching Writing to Scaffold Students in Online Learning
}

\author{
Desi Sri Ayu Hutabarat*, Wawan Gunawan \\ English Education Department, Universitas Pendidikan Indonesia \\ *Corresponding author. Email: desisriayu@upi.edu
}

\begin{abstract}
A Genre Based Approach (GBA) is the concept of teaching to teach students in the text level by involving the stages of teaching that follows the concept of scaffolding. Some scholars had tried to contextualize, and to see the portrait of how GBA implemented in the teaching of writing in various levels. However, the implementation and the portrait on how GBA is used to scaffold students in online learning has not been studied. As a result, this study aimed to investigate the way teacher implements GBA to scaffold students writing in online learning. This study employed qualitative research design embracing case study approach and involved 1 teacher and 20 students enrolling in a junior high school in Bandung. The data analyzed by using a technique suggested by Miles and Huberman (1994). The result of the analysis showed that in online learning GBA is less effective to scaffold students in the teaching of writing. It is due to the teacher and students do not interact directly and there are several stages of GBA that are difficult to be implemented in online learning. It is recommended that future related research should be conducted in more diverse of educational settings in online learning.
\end{abstract}

Keywords: Genre based approach (GBA), online learning, scaffolding, teaching writing

\section{INTRODUCTION}

The syllabus of English subject aims to develop the competency to communicate in both spoken and written language through integrating the four language skills, listening, speaking, reading and writing. Writing is considered as the most challenging and important skills among all the skills (Elashri, 2013). As one of the productive skills, writing allows the writers to elaborate their thinking, ideas, opinion into a written form. A written idea can be examined, reconsidered, rearranged, and changed until it would be beneficial for a wider community. However, in reality, it is found that there are many students who have problems in writing, even though they are good at speaking. Therefore, there are many approaches that teachers apply in order to improve the students' writing skills. One of the approaches is a Genre-Based Approach (GBA).

A Genre-Based Approach to learning writing is used as a systematic instructional learning media for writing to help learners compile meaningful writing (Byram \& Feng, 2004). In a Genre-Based Approach, language knowledge is linked to social goals where the main focus of the purpose of writing lies in the viewpoint of a reader rather than the point of view of the writer himself. In a Genre-Based Approach, the concept of teaching writing is teaching the students in the text level by involving the stages of teaching namely Building Knowledge of the Field (BkoF), Modelling of the Text (MoT), Joint Construction of the text (JcoT) and Independent Construction (Emilia, 2011). It means that in the Genre-Based Approach, teaching writing does not only teach writing as a final draft but also teaching writing as a series of actions that are taken in to achieve a result. Thus, teaching writing is a process, not an instant product.

Moreover, the implementation of a Genre-Based Approach follows the concept of scaffolding or teachersupported learning (Hyland, 2004). The notion of scaffolding emphasizes the role of interaction by experiencing others in learning, moving learners from their existing level of performance to a level of potential performance. It means that scaffolding helps learners to learn with a teacher's guidance from the very basic of knowledge up to having the ability to do or to create something independently. Furthermore, the concept of scaffolding in a Genre-Based Approach is important since it supports the process of students' individual development. Moreover, Bodrova and Leong (1998) and Nuswantoro and Technique (2011) stated that 
"scaffolding emerged in the teaching stages of a GenreBased Approach (GBA)" (p. 1).

A large number of studies have followed trying to contextualize and to implement a Genre-Based Approach (GBA) in teaching writing (Carstens \& Weideman, 2009; Haryanti \& Sari, 2019; Irawansyah, 2016; Sabouri, Zohrabi \& Vafa, 2014; Tuan, 2011; Varaprasad, 2011; Zurdianto, 2016). Carstens and Weideman (2009) conducted a study on a Genre Based Approach to university students in teaching academic writing where English is used as the first language. Varaprasad, C. (2011) did a study on ESL university students in teaching thesis writing in a university in Singapore. The researcher found that the Genre-Based Approach gave positive impacts to the students. In EFL context, Sabouri et al. (2014) examined the effects of a Genre Based Approach to the Iranian students and found that the Genre-Based Approach was effective in helping Iranian students to learn the organizational structure as well as linguistic features of a certain genre.

In Indonesian context, many researchers have conducted a Genre-Based Approach in various levels such as at primary level (Elashri, 2013)., secondary level (Haryanti \& Sari, 2019) and tertiary level (Irawansyah, 2016). Zurdianto (2016) conducted a study at a lower secondary level of education and found that the Genre-Based Approach enhanced a joyful learning atmosphere and improved the students' learning writing achievement in classification text. Regarding the implementation of a Genre-Based Approach, Irawansyah, (2016) recommended using this approach at the tertiary level. He stated that the students' writing ability underwent the improvement by using the Genre Based Approach and the approach will help the university students in learning English.

Besides, there are also many studies conducted in a case study design to see the portrait of how a Genre Based Approach (GBA) implemented in the classroom; the process, the challenges, the obstacles, and the teachers' perspective in implementing a Genre-Based Approach. In implementing a Genre Based Approach, stated that the difficulties that the teachers faced in the teaching and learning activity are due to the students' lack of vocabulary to construct a short text, the mastery of English grammar, and the limit of time for the students to do the task. In addition, found that teachers should have extra competency to prepare the teaching and learning activity to reduce the teachers' challenges in applying Genre Based Approach.

In other context however, Since the case of coronavirus diseases or known as covid-19 spread and become a global pandemic, it changes many things, especially in education era. According to UNESCO schools are closed in many countries due to a public health emergency. Until the first April 2020, UNESCO recorded at least 1.5 billion school-age children who couldn't attend the school due to the impact of Covid-19 in 188 countries including 60 million of them is in Indonesia. This condition makes every country works hard to find solutions for students to keep on learning and have their education right.

The Ministry of Education and Culture of Indonesia responds with educational policies Number 4/2020. One of the policy is that during the spread of coronavirus disease (Covid-19) the process of teaching and learning in all level of education will be done at home by online learning. This policy forces all of teachers in Indonesia make the transition of the way they teach from face to face learning to online learning. Online learning is an access to learning experiences by using of some technology. Online learning is the part of distance learning. It means that teachers and students do not go to school, but they teach and study from home by using technology. The technology used such as smartphone, laptop, i-pad, or tablets.

Therefore, the implementation and the portrait on how GBA is used to scaffold students in online learning has not been studied. As a result, this study was aimed to investigate whether GBA can be implemented effectively to scaffold students writing in online learning.

\section{METHOD}

The design of this study is qualitative research design embracing case study approach. The focus of all qualitative research needs to be on understanding the phenomenon being explored (Creswell, Hanson, Clark Plano, \& Morales, A, 2007). Yin (1984, as cited in Zaidah, 2007) suggests that descriptive case studies "set to describe the natural phenomena which occur within the data in question." (p. 18). Besides, the goal arranged by the researcher is to describe the data as they are. Thus, the result of this study is not intended to be generalized (Fraenkel, Wallen, \& Hyun, 1993). However, the result of study still can be utilized as a valuable insight to this issue (Klassen, Cresswell, PlanoClark, Smith, \& Meissner, 2012). In this case, the phenomenon investigated were whether GBA can be implemented effectively to scaffold students writing in online learning.

This study involved 1 teacher and 20 students enrolling in a junior high school in Bandung. The teacher who became the participant of this study has applied genre based approach in teaching English in the classroom.

According to Hamied (2016), one of the characteristics of a case study approach is multiple data collection or it is not limited to a single source of data. The data in this study were collected by doing observation (in google classroom), and interview 
(teachers and focused students). This was in the form of a semi-structured interview.

The observation through google classroom was conducted to find out how the teacher implement genre based approach to scaffold students in writing in online learning, whether GBA implemented effectively in online learning. The interview intended to validate or to confirm the data obtained from observation.

The data analyzed by using a technique suggested by Miles \& Huberman (1994). The steps are as follows; first, the researcher interviewed the informant (the teacher) about their understanding about the concept and their knowledge about Genre Based Approach and how they applied it in the process of teaching and learning in online classroom. After that, the researcher checked the components of GBA in every stage. The stage of teaching was observed especially the process of teaching writing, The researcher did data reduction in accordance with the purpose of the research. It was related to the process of selecting, focusing, simplifying and abstracting as well as transforming the raw data which are gained in the research. The researcher grouped the data based on the way they are gained. The data classified into two groups; they were data from interview and teaching observation. Second, the data from the observation in google classroom and google meeting were transcribed by listening and watching the video types several times while reading the field notes. The data gain analyzed to know the process of GBA to scaffold the students in writing recount text in online teaching and learning process based on the notes and video taken in the google meeting classroom. Third, the data from the observation coded. In other words, after transcribing the data, the researcher selected specific data to use (relevant to the research questions) and disregard other data that do not specifically provide evidence in this study. Lastly, the researcher concludes.

\section{FINDINGS AND DISCUSSION}

This study aimed to investigate whether GBA can be implemented effectively to scaffold students writing in online learning. The result of this research showed that the teacher in this study conducted some activities to scaffold the students to write in online learning. The data findings are displayed in the order of the stages of genre based approach such as building knowledge of field, modelling, joint construction, and independent construction.

\subsection{Building knowledge of field}

To begin the lesson, the teacher prepares the students with the topic by giving the students some videos of storytelling about the experience of someone. The person in the story told about her experience in having a holiday. The teacher asked the students to take notes while watching the video. After watching the videos, the teacher asked the students about the videos. This part familiarizes the students with the topic being studied. In this part, the teacher did not tell the students the genre of text they studied. The teacher wanted the students to find out the genre they studied by themselves.

In this step, the teacher gave the students some questions and tasks based on the video. As in meeting one, the students seemed to have no difficulties doing the teacher's instruction and in responding to the teacher's questions. In building knowledge of the field, the students could find the genre type they studied by watching the videos and answering the teacher's questions.

\subsection{Modelling}

After building knowledge of the field, the next step is modelling. In modelling, the students' activities in this stage include unpacking the context and language of the text such as the purpose and the structure of the text, and the linguistic features used in the text. In modelling the text, the teacher found difficulties since it is done in online learning.

In this step, the teacher gave the students some examples of recount text by sharing zoom screen with the students. After share screening, the teacher asked the students to read the text. In this phase, reading is dominant. The teacher asked the students about the text; the function of the text and the schematic structure of the text. However, it didn't run well, since it was conducted in online learning, almost all of the students turn off their video, and didn't answer the teacher's questions. So, the teacher didn't know whether the students know the function and the schematic structure of the text or not. Due to the students' unrespond to the teacher questions about the text structure, the teacher asked the students to do it at home after their zoom meeting. However, at that moment, the teacher asked the students to look for related vocabularies and grammar in the text. Even though the teacher should paid attention how the sample text was structured, the teacher just focused on making the students able to write a text by giving explanation and exercises that focused on grammar and related vocabularies.

In this stage, it seems that the process of modelling a text had a misconception and made the students did not took attention to the text structure, but the students focused only to the vocabularies and the grammar in the text. It was also can be seen from the students' task to analyse the text, the teacher found that there were many students who cannot analyse the structure of the text well. 


\subsection{Joint Construction}

The joint construction stage is the moment in which the teacher and students collaborate to construct the focus text. No activity of joint construction can be identified since the teacher and the students just interact in online learning.

The activity in which the teachers and students collaborate to construct the focus text did not take place in online class in the joint construction stage. In practice, the activity that could be identified was that the teachers let the students themselves did the task in groups seemed to be difficult to be done in online learning because the students were not in the same room. The teacher seemed difficult to observe the students in practicing giving questions and answers. It was also difficult because some of the students have less concentration. In addition, the teachers did not provide their students with the sample text they were supposed to construct, but they provided clues of what to be there in constructing the text.

\subsection{Independent Construction}

After all the stages, in this stage, the teacher asked the students to write about their experience, since the genre that being studied was about recount text. But before the students create their text, the teacher reviews the structure of the text to make sure the students' text would write their text based on the teacher's explanation.

In fact, in this stage, the teacher should not explain the generic structure of the text. It should be explained in the modelling text. However, in the previous stages, the teacher only focused on the vocabularies and the grammar. Thus, it can be concluded that the process of genre based approach was not implemented well. Some steps were missed in the previous stages.

However, when the teacher asked all the students to write their text and submit their assignments through google classroom, many students were able to do the task well. In this stage, the students were able to create their recount text. It can be seen from the result of their writings. The students wrote their text in a good structure of recount text. They began their text with the orientation that introduces the participant, the place, and the time when the story took place. After writing the orientation, the students write some events in the second and the third paragraph. In the end, they wrote the reorientation. Although some students couldn't write their text in good structure, their choice of vocabulary and the use of grammar were good enough. Hence, it seems that the process of GBA also developed the students' language competence. It can be seen from the result of the students text before and after the teacher applied the genre based approach.

\subsection{Teacher's Difficulties}

Teacher's difficulties in implementing GBA in the teaching and learning activity to scaffold students in online learning arise from the students' side and also the teachers' side. According to the teachers, there are four problems faced by the teacher in implementing GBA that arise from the students' side. First, the students in an online classroom have different level of competency; second, the lack of vocabulary; third, the mastery of English grammar; and fourth, the limit of time to understand the material. Furthermore, the students had less concentration in online learning and almost all the students turn off the video when having zoom meeting. It is recommended that all the students should opened the video when having online teaching and learning.

From the teacher's side, the teacher seemed lack of understanding in the stages of modelling, and joint construction in which the activity should be more on writing. Furthermore, in independent construction the teacher still explained about the generic structure of recount text whereas in this stage the students should just wrote their own text without the explaination about the generic stucture of the text again.

\section{CONCLUSION}

Genre-based pedagogy is one of the teaching and learning strategies to assist students to develop their literacy in language, especially English language. It has special stages that scaffold students to reach their ability to write texts for different purposes. Teachers may creatively design the activities in order to make their students aware of the purpose of the target text and the structure of the text. They also lead to pay attention to the grammatical element of how to make the text meaningful.

The result of this research is the description of the implementation of Genre based Approach (GBA) to the teaching writing of English in online learning. The use of genre-based pedagogy in teaching writing has proven to support students to be able to write the focus genre. The use of GBA in the teaching of English provided the development of the teachers' teaching competency, the students' language proficiency. As the students learn the content of the text, their language skills were developed and the mastery of vocabulary and grammar increased. The development of language skills and the mastery of vocabulary and language grammar influence the ability to communicate.

However, in online learning, Genre Based Approach (GBA) is less effective to scaffold students in the teaching of writing. It is because the teacher and students do not interact directly and there are several 
stages of GBA that are difficult to be implemented in online learning such as modelling and joint construction of text

\section{REFERENCES}

Bodrova, E., \& Leong, D. (1998). Scaffolding emergent writing in the zone of proximal development. Literacy, Teaching and Learning, 3(2), 1-18.

Byram, M., \& Feng, A. (2004). Culture and language learning: Teaching, research and scholarship. Language Teaching, 37(3), 149-168. https://doi.org/10.1017/S0261444804002289

Carstens, A., \& Weideman, P. A. J. (2009). The effectiveness of genre-based approaches in teaching academic writing: Subject-specific versus cross-disciplinary emphases (Unpublished doctoral dissertation). University of Pretoria.

Creswell, J. W., Hanson, W. E., Clark Plano, V. L., \& Morales, A. (2007). Qualitative research designs: Selection and implementation. The Counseling Psychologist, 35(2), 236-264. https://doi.org/10.1177/0011000006287390

Elashri, I. I. E. A. F. (2013). The impact of the direct teacher feedback strategy on the EFL secondary stage students' writing performance. Online Submission, 1-99.

Emilia, E. (2011). Pendekatan genre-based approach dalam pengajaran. UPI Press.

Fraenkel, J. R., Wallen, N. E., \& Hyun, H. H. (1993). How to design and evaluate research in education. The McGraw-Hill Companies, Inc.

Haryanti, H., \& Sari, F. (2019). The use of genre-based approach to improve writing skill in narrative text at the eleventh grade students of SMA Ethika Palembang. English Community Journal, 3(1), 280. https://doi.org/10.32502/ecj.v3i1.1693

Hamied, F. A. (2016). Research methods: A guide for first time researchers. UPI Press.

Hyland, K. (2004). Genre and second language writing. University of Michigan Press.

Irawansyah, I. (2016). Genre based approach: A way to enhance students writing ability. English Education: Jurnal Tadris Bahasa Inggris IAIN Raden Intan, 9(1), 74-88. https://doi.org/10.24042/ee-jtbi.v9i1.420

Klassen, A. C., Creswell, J., Plano Clark, V. L., Smith, K. C., \& Meissner, H. I. (2012). Best practices in mixed methods for quality of life research. Quality of Life Research, 21(3), 377-380. https://doi.org/10.1007/s11136-012-0122-x
Miles, M. B., \& Huberman, A. M. (1994). Qualitative data analysis: An expanded sourcebook. Sage.

Nuswantoro, D., \& Technique, S. (2011). The use of scaffolding technique to improve the students' competence in writing genre-based texts. Parole: Journal of Linguistics and Education, 2(1 April), 101-109. https://ejournal.undip.ac.id/index.php/parole/article /view/1578

Sabouri, H., Zohrabi, M., \& Vafa, A. (2014). Genrebased approach to teaching writing in EFL context. International Journal of Applied Linguistic Studies, 3(1), 1-7.

Tuan, L. T. (2011). Teaching writing through genrebased approach. Theory and Practice in Language Studies, 1(11), 1471-1478. https://doi.org/10.4304/tpls.1.11.1471-1478

Varaprasad, C. (2011). Effects of genre-based framework on students' writing. Paper presented at Proceedings of the 3rd International Conference on Future of Education, Florence Italy. http://nus.edu.sg/celc/research/books/4th\%20Symp osium\%20proceedings/17).\%20Chitra\%20Varapra sad.pdf

Zaidah, Z. (2007). Case study as a research method. Jurnal Kemanusiaan, 5(1), 1-6. https://doi.org/10.4135/9781473915480.n2

Zurdianto. (2016). Genre based approach to teaching narrative writing. Al-Tsaqafa: Jurnal Ilmiah Peradaban Islam, 13(01), 99-114. https://journal.uinsgd.ac.id/index.php/jat/article/vie w/1834 